\title{
PENGARUH BELANJA DAERAH TERHADAP INDEKS PEMBANGUNAN MANUSIA DI PROVINSI PAPUA PERIODE 2011 HINGGA 2013 DALAM PERSPEKTIF EKONOMI ISLAM1)
}

\author{
Firly Dwitya Kamilia \\ Program Studi S1 Ekonomi Islam-Fakultas Ekonomi dan Bisnis-Universitas Airlangga \\ Email: firlyyd@gmail.com \\ Tika Widiastuti \\ Departemen Ekonomi Syariah-Fakultas Ekonomi dan Bisnis-Universitas Airlangga \\ Email:widasus@yahoo.com
}

\begin{abstract}
:
The aim of this study was to determine the effect of education spending and health spending on the Human Development Index (HDI) in Papua Province period 2011-2013. The method used is quantitative method with panel data regression techniques. The data used is secondary data by collecting data annual financial statements Papua Province in the period 2011-2013 which includes education and health spending data across district in the province of Papua.

Panel data regression conducted showed that spending on education $\left(X_{1}\right)$ positive and significant impact on the human development index in province of Papua and health spending $\left(X_{2}\right)$ has no effect on the human development index in Papua as well as spending on education and helath spending simultaneously affect the human development index in Papua Province 2011-2013.
\end{abstract}

Keywords: Education Spending, Health Spending, Human Development Index

\section{PENDAHULUAN}

Pembangunan pada negaranegara yang sedang berkembang mulai dilancarkan pada tahun 1960-an. Negaranegara tersebut menghadapi permasalahan-permasalahan besar dalam mencapai kemajuan bangsa, khususnya dibidang sosial ekonomi. Umumnya ada dua modal pokok yang penting bagi negara-negara berkembang untuk mengatasi keterbelakangan yaitu sumber daya alam yang memadai dan sumber daya manusia yang memadai. Sumber daya manusia mempunyai fungsi ganda yaitu di samping sebagai faktor pembangunan juga sebagai tujuan dari pembangunan itu sendiri sehingga memerlukan suatu pengelolaan yang tepat. Seperti halnya dalam surat Q.S AlBaqarah ayat 30 yang menunjukkan manusia sebagai khalifah di bumi.

Istilah pembangunan manusia (human development) dipopulerkan oleh the United Nation Development Program (UNDP) melalui Human Development Report pada tahun 1990. Salah satu strategi untuk meningkatkan sumber daya manusia adalah meningkatkan daya produksi manusia. Hal ini berkaitan dengan pandangan bahwa manusia adalah modal (human capital). Strategi ini menuntut investasi besar dalam pendidikan, pelatihan dan kesehatan.

Menurut Rivai (2009, 294-296), pendidikan dan pelatihan sangat penting

1) Jurnal ini merupakan bagian dari skripsi Firly Dwitya Kamilia, NIM : 041211433092, yang diuji pada 9 Februari 2016 
Kamilia, et al/Jurnal Ekonomi Syariah Teori dan Terapan Vol. 3 No. 5 Mei 2016: 359-374; PENGARUH BELANJA DAERAH TERHADAP INDEKS PEMBANGUNAN MANUSIA DI PROVINSI PAPUA PERIODE 2011 HINGGA 2013 DALAM PERSPEKTIF EKONOMI ISLAM

untuk meningkatkan kinerja saat ini dan kinerja di masa yang akan datang. Manusia diberi keistimewaan oleh Allah SWT melebihi makhluk lainnya yaitu berupa akal sehingga manusia dapat mengembangkan potensinya dan menjalankan tugas sebagai khalifah di bumi untuk mengatur segala sesuatu dibumi serta menegakkan kebenaran dan keadilan. Selain pendidikan, kesehatan menjadi hal penting dalam hidup manusia. Menurut Wang (2015: 2), efek perbaikan terhadap tingkat atau kualitas kesehatan dapat mempengaruhi produktifitas pekerja dan tingkat kualitas sumber daya manusia, yang pada akhirnya menuntun hal tersebut terhadap kinerja perekonomian yang lebih baik. Menurut Huda (2012:65), kemakmuran atau kesejahteraan merupakan tujuan pemerintahan dalam Islam. Pendistribusian sumber daya dan kekayaan, negara dapat melakukan dengan intervensi langsung ataupunmelalui regulasi. Bentuk intervensi langsung tersebut antara lain dengan menggunakan anggaran pendapatan dan belanja negara.

Papua merupakan sebuah provinsi di Indonesia yang terletak di pulau Nugini bagian barat atau west New Guinea. Pada tahun 2004, Provinsi Papua dibagi menjadi dua provinsi oleh pemerintah Indonesia, yaitu bagian timurnya tetap memakai nama Provinsi Papua, sedangkan bagian baratnya menjadi Irian Jaya Barat yang sekarang menjadi
Provinsi Papua Barat. Pembangunan di Papua masih belum merata, padahal provinsi ini memiliki sumber daya alam yang melimpah dan banyak potensipotensi di tanah Papua yang belum sepenuhnya di eksplor diantaranya pariwisata, perindustrian dan perdagangan, hortikultura, pertambangan dan sebagainya. Potensipotensi tersebut akan dikembangkan dengan baik dan dapat terasa manfaatnya untuk kemakmuran masyarakat Papua apabila dikelola dengan tepat oleh sumber daya manusia yang memadai.

Nilai indeks pembangunan manusia Provinsi Papua merupakan nilai IPM paling rendah dibandingkan provinsi lain di Indonesia. Provinsi Papua termasuk tiga provinsi terendah pada tahun 2014 dalam variabel IPM yaitu Angka Harapan Hidup indikator dimensi kesehatan s.erta provinsi terbawah di Indonesia dalam hal rata-rata lama sekolah sebagai salah satu indikator dimensi pendidikan. Wolf dan Zohlnhofer (2009:230) berpendapat bahwa pendidikan cenderung meningkatkan produktifitas karyawan dan dalam hal pekerjaan mereka serta pendapatan pribadi mereka. Meningkatkan pendidikan dan pelatihan adalah penting jika negara ingin tetap kompetitif (Sedighi dan Mehrdad, 2014:244).

Beberapa hasil penelitian menunjukkan bahwa pengeluaran di sektor publik sangat bermanfaat untuk 
Kamilia, et al/Jurnal Ekonomi Syariah Teori dan Terapan Vol. 3 No. 5 Mei 2016: 359-374; PENGARUH BELANJA DAERAH TERHADAP INDEKS PEMBANGUNAN MANUSIA DI PROVINSI PAPUA PERIODE 2011 HINGGA 2013 DALAM PERSPEKTIF EKONOMI ISLAM

meningkatkan pembangunan manusia seperti yang telah dilakukan oleh Brata (2005), Joshi (2012) dan Prasetyo \& Zuhdi (2013). Konsep pembangunan manusia di Provinsi Papua dapat dijadikan fokus pembangunan oleh pembuat kebijakan mengenai arah kebijakan yang mampu mendukung program pembangunan manusia secara maksimal.

Berdasarkan latar belakang yang telah dikemukakan, maka penulis akan meneliti dan menganalisis mengenai pembangunan manusia provinsi Papua dengan melihat bagaimana pengaruh belanja pemerintah sektor kesehatan dan pendidikan secara parsial dan simultan terhadap indeks pembangunan manusia di Provinsi Papua periode 2011-2013 dalam perspektif ekonomi Islam? Bagaimana pandangan Ekonomi Islam tentang pengaruh belanja pendidikan dan belanja kesehatan terhadap Indeks Pembangunan Manusia (IPM)?

\section{LANDASAN \\ TEORI PENGEMBANGAN HIPOTESIS}

Menurut UNDP, pembangunan manusia didefinisikan sebagai suatu proses memperbesar pilihan-pilihan bagi penduduk. Fokus pembangunan yang sesungguhnya adalah penduduk atau manusia itu sendiri karena penduduk merupakan kekayaan nyata suatu bangsa. Menurut Salim dkk (2003:19), pembangunan kualitas manusia sebenarnya suatu upaya yang terencana untuk meningkatkan kapasitas individu dan masyarakat suatu bangsa untuk dapat secara aktif menentukan masa depannya dalam rangka mencapai kesejahteraan material dan spiritual. Menurut Widodo dkk (2011:26) pembangunan manusia merupakan salah satu indikator bagi kemajuan suatu negara. Suatu negara dikatakan maju bukan saja dihitung dari pendapatan domestik bruto saja tetapi juga mencakup aspek harapan hidup serta pendidikan masyarakatnya.

Menurut BPS (2015), istilah pembangunan manusia (human development) ini pertama kali dipopulerkan oleh the United Nations Development Program (UNDP) pada tahun 1990 dan dipublikasikan secara berkala dalam laporan tahunan berupa Human Development Report (HDR). Dalam HDR tersebut dikeluarkan laporan tahunan mengenai Indeks Pembangunan Manusia (IPM) atau Human Development Index (HDI). Indeks Pembangunan Manusia (IPM) mengukur capaian pembangunan manusia berbasis sejumlah komponen dasar kualitas hidup. Sebagai ukuran kualitas hidup, IPM dibangun melalui pendekatan tiga dimensi dasar. Dimensi tersebut mencakup umur panjang dan sehat, pengetahuan, dan kehidupan yang layak. Ketiga dimensi tersebut memiliki pengertian sangat luas karena terkait banyak faktor. Pengukuran dimensi kesehatan, digunakan angka harapan hidup waktu lahir. Selanjutnya untuk mengukur dimensi pengetahuan digunakan gabungan indikator harapan 
Kamilia, et al/Jurnal Ekonomi Syariah Teori dan Terapan Vol. 3 No. 5 Mei 2016: 359-374; PENGARUH BELANJA DAERAH TERHADAP INDEKS PEMBANGUNAN MANUSIA DI PROVINSI PAPUA PERIODE 2011 HINGGA 2013 DALAM PERSPEKTIF EKONOMI ISLAM

lama sekolah dan rata-rata lama sekolah. Adapun untuk mengukur dimensi hidup layak digunakan indikator kemampuan daya beli masyarakat terhadap sejumlah kebutuhan pokok yang dilihat dari ratarata besarnya pengeluaran per kapita sebagai pendekatan yang mewakili capaian pembangunan untuk hidup layak. Menurut Salim dkk (2003:19), pendekatan IPM ini dapat digunakan untuk perencanaan pengembangan peningkatan sumber daya manusia yang menyangkut dimensi kesehatan, pendidikan dan kesejahteraan.

Menurut Yussof dan Nain (2003:103113), selain menyembah atau beribadah, manusia juga bertanggungjawab untuk memelihara dunia dan seluruh isinya berdasarkan prinsip yang ditentukan oleh Allah. Tanggung jawab dan amanah ini harus dapat dilaksanakan manusia karena Allah telah memberikan ilmu pengetahuan yang secukupnya kepada manusia dan malaikat pun bersujud kepada manusia dengan kelebihan tersebut. Tinggi atau rendahnya manusia di hadapan Allah diukur berdasarkan sejauh mana mereka percaya keesaanNya dan mentaati perintah-Nya serta dapat melaksanakan tugas khalifah dengan baik semasa hidupnya di dunia.

Konsep pembangunan dari perspektif Islam bahwa manusia merupakan agen pembangunan. Hal tersebut menekankan betapa pentingnya peranan manusia dalam setiap usaha pembangunan dan manusia menjadi fokus utama dalam pembangunan itu sendiri. Manusia harus membangun potensi yang ada pada dirinya untuk kebaikan dirinya, manusia lain dan alam sekitar. Pentingnya akhlak dalam Islam tidak dapat diabaikan. Nilai akhlak di sisi Islam adalah tinggi kedudukannya karena akhlak tidak boleh dipisahkan dari agama. Tujuan utama yang hendak dicapai dalam pembangunan Islam ialah melahirkan manusia ataupun masyarakat yang kualitas akhlaknya tinggi. Menurut Yussof dan Nain (2003:112), pembangunan dalam Islam bukan hanya menekankan pembangunan material semata, tetapi turut menekankan pembangunan akidah masyarakat dan pembangunan akhlak mereka. Shaykh Muhammad Qutb mengatakan bahwa dimensi pembangunan insan adalah pembangunan

kerohanian, pembangunan akal dan pikiran (mind) dan pembangunan fisiologikal. Perkembangan moral manusia adalah kepentingan dasar bagi Islam. Penting bagi individu di dalam masyarakat untuk memiliki kesempatan mempraktikkan kebaikan secara sengaja. Chamid (2010:313) berpendapat bahwa kedermawanan, kemurahan hati dan kebaikan hati lainnya menjadi suatu yang hidup dalam masyarakat. Islam tidak bersandar seluruhnya pada hukum untuk menegakkan keadilan, tetapi memberikan otoritas utama kepada pembentukan moral manusia seperti iman, taqwa, pendidikan dan lainnya. 
Kamilia, et al/Jurnal Ekonomi Syariah Teori dan Terapan Vol. 3 No. 5 Mei 2016: 359-374; PENGARUH BELANJA DAERAH TERHADAP INDEKS PEMBANGUNAN MANUSIA DI PROVINSI PAPUA PERIODE 2011 HINGGA 2013 DALAM PERSPEKTIF EKONOMI ISLAM

Islam menegaskan bahwa wilayah operasi pembangunan adalah manusia di dalam maupun di luar. Misalnya sikapsikap manusia, insentif, selera aspirasi sebanding dengan sumber fisik, modal, tenaga kerja, pendidikan, ketrampilan, organisasi dan sebagainya. Hasil dari pembangunan yang dilakukan terhadap manusia tersebut dapat melibatkan partisipasi rakyat sebanyak mungkin dalam proses pengambilan keputusan maupun impelementasi perencanaan.

Pendapatan negara adalah hak pemerintah pusat yang diakui sebagai penambah nilai kekayaan bersih, artinya semua penerimaan yang menjadi hak pemerintah pusat yang berkaitan dengan pelaksanaan tugas pokok dan fungsi kantor/satuan kerja/ kementrian negara/ lembaga (Huda, 2012: 84). Sementara itu, sumber-sumber penerimaan harta publik (baitulmal) dalam negara Islam di zaman Nabi Muhammad SAW dan para khalifah awal mencakup zakat, 'usyr, khums, fai', jizyah dan kharaj. Semua sumber pemasukan negara tersebut diadakan dan digunakan oleh negara untuk membiayai berbagai pengeluaran terpenting untuk menangani berbagai pengeluaran, disamping juga untuk mendistribusikan kekayaan di antara golongan masyarakat miskin dan kaya (Chaudry, 2012: 253-254).

\section{Pengertian}

pengeluaran

pemerintah dalam arti riil dapat dipakai sebagai indikator besarnya kegiatan pemerintah yang dibiayai oleh pengeluaran pemerintah itu. Semakin besar dan banyak kegiatan pemerintah semakin besar pula pengeluaran pemerintah yang bersangkutan (Suparmoko, 2000: 22).

Model Pembangunan Tentang Perkembangan Pengeluaran Pemerintah Model ini dikembangkan oleh Rostow dan Musgrave yang menghubungkan perkembangan pengeluaran pemerintah dengan tahaptahap pembangunan ekonomi yang dibedakan antara tahap awal, tahap menengah, dan tahap lanjut.

Hukum Wagner

Wagner mengemukakan suatu teori mengenai perkembangan pengelvaran pemerintah yang semakin besar dalam presentase terhadap GNP yang didasarkan pula pengamatanpengamatan di negara Eropa, U.S dan Jepang pada abad ke -19.

Teori Peacock dan Wiseman

Teori ini didasarkan pada suatu pandangan bahwa pemerintah senatiasa berusaha untuk memperbesar pengeluaran sedangkan masyarakat tidak suka membayar pajak yang semakin besar untuk membiayai pengeluaran pemerintah yang semakin membesar tersebut. Peacock dan Wiseman mendasarkan teori mereka pada suatu teori bahwa masyarakat mempunyai suatu tingkat toleransi pajak yang dibutuhkan oleh pemerintah untuk membiayai pengeluaran pemerintah. Jadi masyarakat menyadari bahwa 
Kamilia, et al/Jurnal Ekonomi Syariah Teori dan Terapan Vol. 3 No. 5 Mei 2016: 359-374; PENGARUH BELANJA DAERAH TERHADAP INDEKS PEMBANGUNAN MANUSIA DI PROVINSI PAPUA PERIODE 2011 HINGGA 2013 DALAM PERSPEKTIF EKONOMI ISLAM

pemerintah membutuhkan dana untuk membiayai aktivitas pemerintah sehingga mereka mempunyai suatu tingkat kesediaan masyarakat untuk membayar pajak.

Jadi berbeda dengan pandangan Wagner, perkembangan pengeluaran pemerintah versi Peacock dan Wiseman tidak berbentuk garis, tetapi berbentuk seperti tangga karena adanya toleransi pajak tersebut.

Menurut Ibnu Taimiyah, prinsip dasar dari pengelolaan pengeluaran adalah pendapatan yang berada di tangan pemerintah atau negara merupakan milik masyarakat sehingga harus dibelanjakan untuk kebutuhan masyarakat sesuai dengan pedoman Allah SWT (Huda, 2012: 191). Berdasarkan analisis ekonomi terhadap sejarah pengeluaran publik Islam semasa Rasululah SAW dan Khulafaurrasyidin serta kaidah fikih muamalah, pada hakikatnya prinsip utama dalam pengalokasian dana publik adalah peningkatan maslahah tertinggi.

Menurut UU Nomor 20 Tahun 2003 untuk memenuhi hak warga negara, pemerintah pusat dan pemerintah daerah wajib memberikan layanan dan kemudahan serta menjamin terselenggaranya pendidikan yang bermutu. Pemerintah pusat dan pemerintah daerah wajib menjamin tersedianya dana pendidikan selain gaji pendidik dan biaya pendidikan kedinasan minimal $20 \%$ dari APBN dan APBD pada sektor pendidikan guna terselenggaranya pendidikan bagi setiap warga negara yang berusia tujuh sampai dengan lima belas tahun.

Sedangkan pengeluaran publik di sektor kesehatan menurut pasal 171 UU Nomor 36 Tahun 2009 menjadi sesuatu yang mutlak dipenuhi (mandatory spending). Pemerintah wajib mengalokasikan anggaran kesehatan sebesar minimal 5\% (lima persen) dari APBN di luar gaji, sementara pemerintah provinsi dan kabupaten/kota mengalokasikan anggaran kesehatan minimal 10\% (sepuluh persen) dari APBD di luar gaji. Tujuan dari pembangunan bidang kesehatan adalah tercapainya derajat kesehatan yang terus membaik. Departemen Kesehatan menyebutkan pengelvaran publik bidang kesehatan dibelanjakan untuk farmasi, obat-obatan, peralatan medis, rumah sakit dan pusatpusat kesehatan masyarakat (Puskesmas). Menurut Gupta et. al (1998) dalam Prasetyo dan Zuhdi (2013:615), pengeluaran pemerintah dalam sektor kesehatan dan pendidikan dapat membawa efek yang positif bagi human capital, yang pada akhirnya meningkatkan pertumbuhan ekonomi saat pemerataan menjadi salah satu topik utama dan dapat menurunkan kemiskinan. Modal manusia yang berpendidikan dan sehat adalah fakor yang signifikan dari keunggulan pembentukan negara yang kompetitif. Hal itu mempengaruhi efisinesi tenaga 
Kamilia, et al/Jurnal Ekonomi Syariah Teori dan Terapan Vol. 3 No. 5 Mei 2016: 359-374; PENGARUH BELANJA DAERAH TERHADAP INDEKS PEMBANGUNAN MANUSIA DI PROVINSI PAPUA PERIODE 2011 HINGGA 2013 DALAM PERSPEKTIF EKONOMI ISLAM

kerja dan produktivitas, yang pada gilirannya menarik investasi asing ke negara. Kesehatan dan pendidikan yang lebih baik akan menarik vang ke dalam perekonomian suatu negara. Tenaga kerja yang terdidik dan sehat sering menjadi pengaruh fundamental untuk investor asing ketika membua sebuah keputusan tentang investasi modal (Malik, 2013 dalam Lonska \&Boronenka, 2015:1031).

Investasi publik di bidang pendidikan dan kesehatan akan memberikan kesempatan dan pelayanan ksehatan yang lebih merata kepada masyarakat sehingga sumber daya manusia (SDM) handal yang sehat menjadi semakin bertambah. Meningkatnya kesehatan dan pendidikan akan mendorong peningkatan kualitas SDM dan peningkatan produktivitas tenaga kerja, yang pada gilirannya akan meningkatkan pendapatan masyarakat serta pada akhirnya akan meningkatkan kesempatan kerja dan berkurangnya kemiskinan (Widodo dkk, 2011:31).

\section{Hipotesis}

Berdasarkan pemaparan tinjauan pustaka di atas, maka hipotesis dalam penelitian ini adalah sebagai berikut :

$H_{1}$ : Belanja pemerintah sektor pendidikan dan kesehatan berpengaruh positif secara parsial terhadap Indeks Pembangunan Manusia (IPM) di Provinsi Papua

$\mathrm{H}_{2}$ : Belanja pemerintah sektor pendidikan dan kesehatan berpengaruh positif secara simultan terhadap Indeks Pembangunan Manusia (IPM) di Provinsi Papua

\section{Model Analisis}

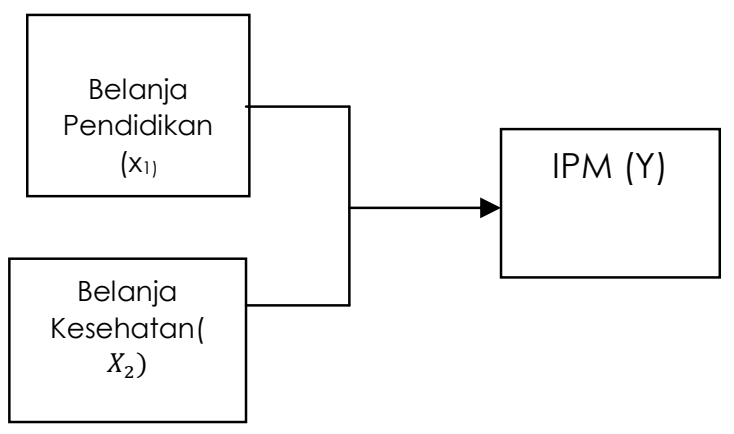

Gambar 1.

Model Analisis Penelitian

\section{METODE PENELITIAN}

\section{Pendekatan Penelitian}

Penelitian ini menggunakan pendekatan metode penelitian kuantitatif. Metode ini disebut metode kuantitatif karena data penelitian berupa angka-angka dan analisisnya menggunakan statistik (Sugiyono, 2009: 12).

\section{Identifikasi Variabel}

Variabel independen dalam penelitian ini adalah pengeluaran pemerintah di sektor pendidikan $\left(X_{1}\right)$ dan pengelvaran pemerintah di sektor kesehatan $\left(X_{2}\right)$ serta variabel dependen adalah indeks pembangunan manusia (Y).

\section{Definisi Operasional}

1. Belanja Pendidikan $\left(X_{1}\right)$ Menurut UU No. 23 Tahun 2013 belanja pendidikan $\left(X_{1}\right)$ adalah belanja pemerintah pusat atau daerah yang digunakan untuk menjalankan fungsi pendidikan. Sedangkan belanja daerah sektor pendidikan adalah pengeluaran di dalam APBD yang dipergunakan 
Kamilia, et al/Jurnal Ekonomi Syariah Teori dan Terapan Vol. 3 No. 5 Mei 2016: 359-374; PENGARUH BELANJA DAERAH TERHADAP INDEKS PEMBANGUNAN MANUSIA DI PROVINSI PAPUA PERIODE 2011 HINGGA 2013 DALAM PERSPEKTIF EKONOMI ISLAM

mendanai pelaksanaan urusan pemerintah yang menjadi kewenangan kabupaten/kota dalam bidang pendidikan. Data yang digunakan adalah belanja pendidikan kota/kabupaten di Provinsi Papua $2011-2013$.

2. Belanja Kesehatan $\left(X_{2}\right)$ Menurut UU No. 23 Tahun 2013 belanja kesehatan $\left(\mathrm{X}_{2}\right)$ adalah belanja pemerintah pusat atau daerah yang digunakan untuk menjalankan fungsi kesehatan. Belanja daerah sektor kesehatan $\left(X_{2}\right)$ adalah pengeluaran di dalam APBD yang dipergunakan mendanai pelaksanaan urusan pemerintah yang menjadi kewenangan kabupaten/kota dalam bidang kesehatan. Data yang digunakan adalah realisasi belanja kesehatan kabupaten/kota di Papua 201 1-2013.

3. Indeks Pembangunan Manusia (IPM)

IPM adalah indeks komposit untuk mengukur kesejahteraan masyarakat yang terdiri dari tiga komponen yaitu kesehatan yang diukur dengan angka kematian bayi dan angka harapan hidup, pendidikan diukur dengan rata-rata lama sekolah dan harapan lama sekolah serta hidup layak yang diukur dengan paritas daya beli (purchasingpower parity).

\section{Teknik Analisis}

Analisis

regresi dengan menggunakan panel data adalah suatu analisis data kombinasi antara jenis data deret waktu (time series) dan jenis data karat lintang (cross section). Data panel merujuk pada suatu pengamatan pada sebuah cross section dari rumah tangga, negara, perusahaan dan lainnya selama beberapa rentang waktu (Baltagi, 2005). Seluruh data diolah dengan menggunakan software Eviews 7. Langkah pertama dalam teknik analisis ini adalah uji asumsi klasik yakni uji normalitas, uji autokorelasi, uji multikolinieritas, uji heteroskedasitas dan uji linieritas. Setelah seluruh uji asumsi terpenuhi, dilanjutkan uji chow untuk menentukan model PLS atau FEM yang digunakan. Apabila FEM diterima, selanjutnya melakukan uji hausman untuk menentukan model FEM atau REM yang tepat digunakan. Setelah menentukan model yang tepat, uji berikutnya adalah uji $t$ dan uji $F$, lalu koefisien determinasi. Uji † digunakan untuk menguji pengaruh secara parsial variabel independen terhadap variabel dependen, sedangkan uji $\dagger$ digunakan untuk menguji pengaruh secara simultan variabel independen terhadap variabel dependen.

\section{HASIL DAN PEMBAHASAN}

Data yang digunakan lolos uji asumsi klasik. Langkah berikutnya uji chow untuk menentukan model PLS atau FEM yang tepat digunakan. 
Kamilia, et al/Jurnal Ekonomi Syariah Teori dan Terapan Vol. 3 No. 5 Mei 2016: 359-374; PENGARUH BELANJA DAERAH TERHADAP INDEKS PEMBANGUNAN MANUSIA DI PROVINSI PAPUA PERIODE 2011 HINGGA 2013 DALAM PERSPEKTIF EKONOMI ISLAM

Tabel 1.

Hasil Uji Chow

\begin{tabular}{lrr}
\hline \hline Effects Test & Statistic & Prob. \\
\hline \hline Cross-section F & 1199.254454 & 0.0000 \\
Cross-section Chi-square & 556.623780 & 0.0000 \\
\hline \hline
\end{tabular}

Sumber: berdasarkan hasil estimasi menggunakan eviews 7.

Hasil uji chow menunjukkan pvalue sebesar 0,000 yang berarti signifikan atau lebih kecil dari tingkat signifikansi yang di pakai yaitu 5\%. Maka model yang digunakan adalah fixed effect model. Selanjutnya, perlu melakukan uji hausman untuk menentukan model yang akan digunakan yaitu Fixed Effect Model (FEM) atau Random Effect Model (REM).

Tabel 2.

Hasil Uji Hausman

\begin{tabular}{lc}
\hline \hline Test Summary & Prob. \\
\hline \hline Cross-section random & 0.0232 \\
\hline \hline
\end{tabular}

Sumber: berdasarkan hasil estimasi menggunakan eviews 7 .

Berdasarkan hasil di atas, p-value sebesar $0,0232<0,05$ (a) sehingga $\mathrm{H}_{0}$ ditolak dan model yang digunakan dalam penelitian ini adalah fixed effect.

Selanjutnya dilakukan uji $\dagger$ (uji parsial) dan uji $F$ (uji simultan). Variabel belanja pemerintah di sektor pendidikan berpengaruh positif dan signifikan terhadap indeks pembangunan manusia di Provinsi Papua dengan hasil nilai $p$ value sebesar 0,0406 < a sebesar 0,05. Sedangkan, untuk variabel belanja pemerintah di sektor kesehatan tidak terdapat pengaruh terhadap indeks pembangunan manusia di Provinsi Papua karena nilai $p$-value sebesar $0.3102>a$ sebesar 0,05. Hal tersebut dapat dilihat pada hasil uji † di bawah ini.

Tabel 3.

Hasil Uji t-statistik

\begin{tabular}{|ccc|}
\hline \hline Variable & t-Statistic & Prob. \\
\hline \hline LNX1? & 2.096521 & 0.0406 \\
LNX2? & 1.024066 & 0.3102 \\
C & 14.88406 & 0.0000 \\
\hline
\end{tabular}

Sumber: berdasarkan hasil perhitungan menggunakan eviews 7

Secara simultan, hasil uji $F$ yaitu $p$ value sebesar 0,000 lebih kecil dari pada 0,05 (tingkat signifikansi 5\%). Jadi, variabel belanja pemerintah di sektor pendidikan dan sektor kesehatan secara bersamasama berpengaruh positif dan signifikan terhadap indeks pembangunan manusia di Provinsi Papua periode $2011-2013$.

Berdasarkan hasil estimasi FEM dapat dilihat bahwa koefisien determinasi dari hasil regresi di atas yaitu 99,8 persen. Hal ini berarti menjelaskan variasi variabel dependen yaitu indeks pembangunan manusia dapat dijelaskan oleh variabel independen yaitu belanja pendidikan dan kesehatan adalah sebesar 99,8 persen, 
Kamilia, et al/Jurnal Ekonomi Syariah Teori dan Terapan Vol. 3 No. 5 Mei 2016: 359-374; PENGARUH BELANJA DAERAH TERHADAP INDEKS PEMBANGUNAN MANUSIA DI PROVINSI PAPUA PERIODE 2011 HINGGA 2013 DALAM PERSPEKTIF EKONOMI ISLAM

sedangkan sisanya dijelaskan oleh variabel lain yang tidak diteliti atau tidak dimasukkan dalam model penelitian ini.

\section{Pengaruh Belanja Pendidikan terhadap Indeks Pembangunan Manusia di Provinsi Papua tahun 2011-2013}

Hasil penelitian ini menunjukkan bahwa belanja pendidikan $\left(X_{1}\right)$ berpengaruh positif dan signifikan terhadap indeks pembangunan manusia di Papua pada periode 2011 sampai 2013. Hasil analisis belanja pendidikan memiliki nilai sebesar 0,764758. Berdasarkan nilai tersebut dapat dijelaskan bahwa setiap kenaikan belanja pemerintah di sektor pendidikan sebesar satu satuan maka indeks pembangunan manusia akan naik sebesar 0,764758 atau sebaliknya jika pengeluaran pemerintah dalam sektor pendidikan di Papua turun satu satuan maka akan menurunkan indeks pembangunan manusia di Papua sebesar 0,764758. Hal ini menunjukkan meningkatnya belanja pendidikan dapat meningkatkan indeks pembangunan manusia di Papua.

Hal tersebut sesuai dengan keadaan pendidikan di Provinsi Papua, yaitu dengan bertambahnya jumlah sekolah Taman Kanak-Kanak (TK) dan sarana PAUD serta partisipasi Pendidikan Anak Usia Dini (PAUD) yang menjadi program Pendidikan Untuk Semua (PUS) dari Kementrian Pendidikan. Berdasarkan Susenas (2015), partisipasi PAUD pada tahun 2011 sebesar 11,92 \% dan pada tahun 2013 sebesar 12,04\%. Selain itu, pada tahun 2013 terjadi peningkatan tenaga pendidik PAUD dan TK secara drastis di Provinsi Papua sekitar 900 orang.

Berdasarkan BPS (2015), Provinsi Papua mengalami tren positif pada Angka Partisipasi Sekolah (APS) dari tahun 2011 hingga 2013 sebesar 73,36\% hingga $75,51 \%$. Walaupun perkembangannya lambat, namun partisipasi anak sekolah telah menuju ke arah yang diharapkan sebesar 100\%. Selain APS meningkat, Angka Partisipasi Kasar (APK) yang memberikan gambaran secara umum tentang banyaknya anak yang sedang menerima pendidikan dasar, menengah dan ke atas juga meningkat 2,23 poin pada tahun 2013 dibanding capaian pada tahun 2012, dan presentase Angka Melek Huruf (AMH) tahun 2012 hingga 2013 mengalami kenaikan yaitu $76,95 \%$ hingga $82,27 \%$.

Berdasarkan BPS Provinsi Papua (2015), peningkatan guru sekolah agama Islam pun meningkat pada tahun 2011 hingga 2013 sekitar 15 orang guru. Sedangkan, untuk sekolah-sekolah agama Islam yaitu Radhatul Athfal, Madrasah Ibtidaiyah dan Madrasah Tsanawiyah. tidak terjadi peningkatan pada periode 2011 hingga 2013. Hal tersebut diduga disebabkan karena mayoritas penduduk Provinsi Papua beragama non-Islam.

Fasilitas pendidikan yaitu pendidik dan sarana prasarana di Provinsi Papua mengalami peningkatan dari tahun 2011 hingga tahun 2013. Berdasarkan BPS (2015) peningkatan jumlah SD sebesar 110 sekolah, peningkatan jumlah SMP sebesar 
Kamilia, et al/Jurnal Ekonomi Syariah Teori dan Terapan Vol. 3 No. 5 Mei 2016: 359-374; PENGARUH BELANJA DAERAH TERHADAP INDEKS PEMBANGUNAN MANUSIA DI PROVINSI PAPUA PERIODE 2011 HINGGA 2013 DALAM PERSPEKTIF EKONOMI ISLAM

45 sekolah, peningkatan jumlah SMA sebesar 22 sekolah dan peningkatan jumlah guru SMP sebesar 543 orang. Selain itu adanya program beasiswa bagi putraputri daerah yang berprestasi untuk melanjutkan sekolah ke jenjang selanjutnya. Program beasiswa ini tidak hanya memberikan beasiswa untuk kuliah di Indonesia tetapi juga beasiswa ke luar negeri. Selain pemerintah daerah, banyak lembaga non profit yang berkontribusi dalam pembangunan pendidikan di Provinsi Papua, salah satunya yaitu Buku Untuk Papua (BUP) yang sudah ada cabang hampir di seluruh Indonesia untuk memberikan bantuan buku-buku kepada masyarakat Papua.

Pengendalian anggaran yang efisien dan efektif merupakan landasan pokok dalam kebijakan pengeluaran pemerintah, yang dalam ajaran Islam di pandu oleh kaidah-kaidah syariah dan penentuan skala prioritas. Selain pendidikan formal yang ditingkatkan untuk mengetahui ilmu pengetahuan, pendidikan terhadap kepribadian dan agama juga sangat berpengaruh untuk mempertahankan nilai moral dan martabat. Pribadi-pribadi yang terlatih untuk memerhatikan himbauan hati nuraninya, punya pendirian dan iman yang kokoh walaupun suasana lingkungan tidak baik. Selain itu pendidikan agama pun sangat penting untuk membentuk kepribadian suatu SDM. Agama berfungsi memperjelas tujuan, cita-cita, arah kebaikan mana yang hendaknya dicapai dan menambah moral force supaya nilai-nilai itu tetap dipegang dalam keadaan bagaimanapun.

\section{Pengaruh Belanja Kesehatan terhadap Indeks Pembangunan Manusia di Provinsi Papua tahun 2011-2013}

Hasil penelitian ini menunjukkan bahwa belanja kesehatan $\left(X_{2}\right)$ tidak berpengaruh signifikan terhadap indeks pembangunan manusia di Papua pada periode 2011 sampai 2013. Hasil analisis belanja pendidikan memiliki p-value sebesar 0,3102 yang lebih besar dari tingkat signifikansi 5 persen. Hal tersebut menunjukkan bahwa belanja pemerintah Papua pada sektor kesehatan tidak terlalu berpengaruh terhadap peningkatan ataupun penurunan indeks pembangunan manusia di Papua.

Hasil penelitian ini konsisten dengan hasil penelitian yang diteliti oleh Nuryadin (2015). Jumlah pengeluaran pemerintah daerah Papua dalam sektor kesehatan jauh lebih kecil dibandingkan dengan pengeluaran pemerintah daerah Papua dalam sektor pendidikan sehingga pemerintah daerah belum optimal meningkatkan fasilitas dan pelayanan kesehatan di Papua. Berdasarkan Direktorat Jenderal Perimbangan Keuangan (DJPK), pengeluaran pemerintah daerah Papua dalam sektor kesehatan periode 2011 sampai 2013 masih dibawah 2 triliun dibandingkan dengan pengeluaran di sektor kesehatan sebesar lebih dari 3 triliun. 
Kamilia, et al/Jurnal Ekonomi Syariah Teori dan Terapan Vol. 3 No. 5 Mei 2016: 359-374; PENGARUH BELANJA DAERAH TERHADAP INDEKS PEMBANGUNAN MANUSIA DI PROVINSI PAPUA PERIODE 2011 HINGGA 2013 DALAM PERSPEKTIF EKONOMI ISLAM

Hal tersebut sesuai dengan potret atau kondisi sektor kesehatan di Provinsi Papua yaitu minimnya fasilitas rumah sakit yang mampu melayani masyarakat Papua. Berdasarkan BPS Provinsi Papua (2015) peningkatan rumah sakit dari tahun 2009 hingga 2012 hanya sebanyak 3 rumah sakit, penurunan polindes dari tahun 2009 hingga 2012 sebanyak 121 polindes. Selain itu, angka kematian ibu dan anak, penyakit menular (malaria dan tubercoluse) tahun 2013 di Provinsi Papua merupakan yang tertinggi di Indonesia dan jumlah penderita penyakit menular di Provinsi Papua dari tahun tahun semakin meningkat.

Tanpa adanya pengelolaan yang bijak, maka akan terjadi inefisiensi dalam pemanfaatan alokasi belanja kesehatan Provinsi Papua. Salah satu dampak inefisiensi adalah terjadinya ketimpangan pembangunan antarwilayah dan tidak dialokasikan secara tidak merata dalam suatu wilayah.

Kesehatan merupakan satu dari maqashid syariah yaitu nasl. Kesehatan dibutuhkan untuk menjaga kontinuitas kehidupan, maka manusia harus memelihara keturunan dan keluarganya. Kelangsungan keturunan dan keberlanjutan dari generasi ke generasi harus diperhatikan untuk menjaga eksistensi manusia. Menjaga hal tersebut, manusia harus sehat untuk menghasilkan keturunan. Maka dari itu, kesehatan merupakan hal yang penting dalam dasar kehidupan manusia.
Tujuan dari adanya anggaran pemerintah adalah menopang tujuan yang ingin dicapai oleh pemerintah. Tujuan pokok dari setiap pemerintahan Islam adalah memaksimalkan kesejahteraan seluruh warga negaranya per individu dengan tidak mengabaikan keadilan. Hal tersebut harus menjadi tujuan dari pemerintah daerah Papua.

Pengaruh Belanja Pendidikan dan Belanja Kesehatan terhadap Indeks

Pembangunan Manusia di Provinsi Papua tahun 2011-2013

Hasil penelitian ini menunjukkan bahwa secara bersama-sama atau simultan belanja pendidikan $\left(X_{1}\right)$ dan belanja kesehatan $\left(\mathrm{X}_{2}\right)$ berpengaruh positif dan signifikan terhadap indeks pembangunan manusia di Papua periode 2011 sampai 2013. Hasil analisis uji $F$ ini memiliki $p$-value sebesar 0,000 lebih kecil dari tingkat signifikansi 5 persen. Hal ini konsisten dengan hasil penelitian Widodo,dkk (2011) pengeluaran pemerintah dalam sektor kesehatan dan pendidikan membawa efek positif bagi peningkatan kualitas SDM.

Kenaikan APBD Provinsi Papua dari tahun ke tahun perlu diapresiasi baik karena komitmen pemerintah daerah Papua dengan meningkatkan belanja sektor pendidikan dan kesehatan selain belanja otonomi daerah. Bidang pendidikan dan kesehatan menjadi salah satu sektor yang diperhatikan oleh pemerintah daerah dengan programprogram dan pembangunan fasilitas. Hal 
Kamilia, et al/Jurnal Ekonomi Syariah Teori dan Terapan Vol. 3 No. 5 Mei 2016: 359-374; PENGARUH BELANJA DAERAH TERHADAP INDEKS PEMBANGUNAN MANUSIA DI PROVINSI PAPUA PERIODE 2011 HINGGA 2013 DALAM PERSPEKTIF EKONOMI ISLAM

tersebut dibuktikan dengan peningkatan jumlah sekolah, jumlah guru dan jumlah murid di Papua serta peningkatan fasilitas pelayanan kesehatan berupa rumah sakit dan puskesmas di Papua (BPS, 2015). Peningkatan pembangunan manusia, keberadaannya terintegrasi dalam perencanaan pembangunan dan penganggaran, oleh karenanya dimensi dalam pembangunan manusia yaitu pendidikan dan kesehatan tertuang dalam dokumen perencanaan daerah begitu pula dengan dimensi ekonomi.

Pendidikan dan kesehatan menjadi sangat penting karena manusia sebagai homo islamicus memerlukan ilmu pengetahuan dan sehat rohani serta jasmani untuk menjalankan tugasnya sebagai khalifah. IImu pengetahuan yang didapat dari lembaga sekolah ataupun lembaga non sekolah dan tubuh serta jiwa yang sehat digunakan untuk ibadah dan kerja untuk memenuhi kebutuhan dirinya dan umat. Hal tersebut dapat membuat manusia menjadi produktif dalam dunia ini untuk mencapai kesuksesan dunia dan akhirat (falah). Sesuai yang dikatakan oleh Yussof dan Nain (2003:113) yaitu manusia yang sempurna adalah manusia yang unggul dalam segi rohani, mampu menyeimbangkan kehendaknya serta sehat akal dan tubuhnya. Pendidikan dan kesehatan juga merupakan salah satu pilar pengentasan kemiskinan dan faktor yang penting untuk indikator indeks pembangunan manusia.
Seperti yang dikemukakan Siddqi (1993) dalam Huda (2012:76) anggaran belanja negara harus digunakan untuk kepentingan yang menjadi prioritas, yaitu pemenuhan kebutuhan dasar, pertahanan, penegakan hukum, dan sebagainya. Pembanfaatan anggaran tersebut untuk kepentingan penyediaan barang publik yang bertujuan meningkatkan kesejahteraan masyarakat.

Pandangan Ekonomi Islam tentang Pengaruh Belanja Pendidikan dan Belanja Kesehatan terhadap Indeks Pembangunan Manusia

Menurut Chaudry (2012:31), tujuan pertama dan paling utama Islam adalah falah atau kebahagiaan umat manusia di dunia ini maupun akhirat. Kesejahteraan menurut ajaran Islam yaitu kecukupan materi yang didukung dengan terpenuhinya kebutuhan spritual untuk memperoleh kesejahteraan di akhirat. Menurut Huda (2015:9), kewajiban merealisasikan falah merupakan tugas pemerintah dan masyarakat. Hakikatnya pemerintah dan masyarakat dapat saling menggantikan dan saling melengkapi sesuai dengan situasi dan kondisi. Pemerintah adalah pemegang amanah Allah untuk menjalan tugas kolektif dalam mewujudkan kesejahteraan dan keadilan.

Sebagaimana yang dikemukakan Abdurrahman Al-Maliki yaitu pemerintah harus menjamin pemenuhan kebutuhan primer per individu secara menyeluruh dan membantu tiap individu untuk memebuhi kebutuhan sekunder dan 
Kamilia, et al/Jurnal Ekonomi Syariah Teori dan Terapan Vol. 3 No. 5 Mei 2016: 359-374; PENGARUH BELANJA DAERAH TERHADAP INDEKS PEMBANGUNAN MANUSIA DI PROVINSI PAPUA PERIODE 2011 HINGGA 2013 DALAM PERSPEKTIF EKONOMI ISLAM

tersiernya sesuai kemampuannya.

Jaminan kebutuhan primer yaitu terpenuhinya sandang, pangan dan papan merupakan jaminan langsung terhadap setiap individu. Jaminan kebutuhan-kebutuhan primer lainnya meliputi keamanan, pendidikan dan kesehatan.Pungutan dari zakat dapat digunakan untuk membiayai pengeluaran daerah ataupun negara. Zakat merupakan bentuk ibadah, sehingga kebanyakan orang berlomba-lomba mau menunjukkan melaksanakan tanggung jawab itu secepat mungkin di hadapan Allah

\section{Simpulan}

Berdasarkan penelitian yang telah dilakukan maka dapat disimpulkan :

1. Variabel belanja pendidikan berpengaruh positif terhadap indeks pembangunan manusia di Papua pada periode 2011 sampai 2013. Hal ini dikarenakan semakin tinggi atau semakin besar pengeluaran pemerintah daerah Papua pada sektor pendidikan akan meningkatkan jumlah sekolah, tenaga pendidik dan jumlah siswa, sehingga rata-rata lama sekolah sebagai indikator dimensi pendidikan dalam indeks pembangunan manusia akan meningkat dan pada akhirnya akan meningkatkan indeks pembangunan manusia di Papua. Variabel belanja kesehatan tidak berpengaruh terhadap indeks pembangunan manusia di Papua pada periode 2011 sampai 2013. Jumlah pengeluaran pemerintah daerah Papua dalam sektor kesehatan jauh lebih kecil dibandingkan dengan pengeluaran pemerintah daerah Papua dalam sektor pendidikan sehingga pemerintah daerah belum optimal meningkatkan fasilitas dan pelayanan kesehatan di Papua.

2. Variabel belanja pendidikan dan belanja kesehatan berpengaruh secara bersama-sama atau simultan terhadap indeks pembangunan manusia di Papua periode 2011-2013.

3. Konsep Islam mengajarkan bahwa belanja negara harus sesuai dengan syariah dan penentuan skala prioritas. Perbedaan kebijakan anggaran dalam ekonomi konvensional dan ekonomi Islam terletak pada tujuan dan prinsip-prinsip pengelolaan anggaran dalam Islam yang berdasarkan Al-Quran dan hadits. Jaminan pemenuhan kebutuhan primer merupakan tanggung jawab pemerintah dalam Islam. Jaminan kebutuhan primer tersebut meliputi sandang, pangan, pakan, keamanan, pendidikan dan kesehatan. Selain itu untuk medistribusikan kekayaan secara adil dan merata, instrumen 
Kamilia, et al/Jurnal Ekonomi Syariah Teori dan Terapan Vol. 3 No. 5 Mei 2016: 359-374; PENGARUH BELANJA DAERAH TERHADAP INDEKS PEMBANGUNAN MANUSIA DI PROVINSI PAPUA PERIODE 2011 HINGGA 2013 DALAM PERSPEKTIF EKONOMI ISLAM

zakat dapat diterapkan dalam membantu permasalahan pemerintahan ini.

\section{DAFTAR PUSTAKA}

Al-Quran.

Agus, Bustinuddin. 2007. Islam dan Pembangunan. Jakarta: PT RajaGrafindo Persada

Badan Pusat Statistik. 2015. Booklet Indeks Pembangunan Manusia Metode Baru Badan Pusat Statistik Provinsi Papua. 2015. http://papua.bps.go.id/ diakses pada tanggal 5 Desember 2015

Brata, Aloysius Gunadi. 2005. Investasi Sektor Publik Lokal, Pembangunan Manusia dan Kemiskinan. Lembaga Penelitian - Universitas Atma Jaya Yogyakarta, Februari

Baltagi, Badi H. 2005. Econometric Analyis of Panel Data. England: John Wiley \& Sons Ltd.

Chamid, Nur. 2010. Jejak Langkah Sejarah Pemikiran Ekonomi Islam. Yogyakarta: Pustaka Pelajar

Chaudry, Muhammad Sharif. 2012. Sistem Ekonomi Islam Prinsip Dasar. Terjemahan oleh Suherman Rosyidi. Jakarta: Kencana Prenada Media Group

Huda, Nurul, dkk. 2012. Keuangan Publik Islami Pendekatan Teoritis dan Sejarah. Jakarta: Kencana Prenada Media Group

2015. Keuangan Publik Pendekatan Instrumen Kebijakan dalam Perspektif
Islam. Jakarta: PT Elex Media Komputindo

Joshi, Devin K. 2012. The Impact of India's Regional Parties on Voter Turnout and Human Development. Journal of South Asian Development 7(12), hlm. 139-160, tersedia dalam www.online.sagepub.com

Lonska, Jelena dan Vera Boronenko. 2015. Rethinking Competitiveness and Human Development in Global Comparative Researches. Journal of Economic and Finance, 23, hlm. 1030-1036, tersedia dalam www.sciencedirect.com

Nuryadin, Arifin. 2015. Pengaruh Penduduk Miskin, Konsumsi Rumah Tangga dan Belanja Pemerintah Terhadap Indeks Pembangunan Manusia di Nusa Tenggara Timur. Skripsi tidak diterbitkan. Surabaya FEB Universitas Airlangga

Prasetyo, Ahmad Danu dan Ubaidillah Zuhdi. 2013. The Government Expenditure Efficiency towards the Human Development. Journals of Economics and Finance, 5, hlm. 615622, tersedia dalam wWW.sciencedirect.com

Rivai, Veithzal. 2009. Islamic Human Capital Dari Teori ke Praktik Manajemen Sumber Daya Islami. Jakarta: PT RajaGrafindo Persada

Salim, Lutfi Agus, dkk. 2003. Penyusunan Indeks Pembangunan Manusia di Kota Surabaya. Surabaya: Badan Perencanaan Kota Surabaya

Sedighi, Majid dan Ali Gholami. 2014. The Productivity Indexes at Islamic Azad 
Kamilia, et al/Jurnal Ekonomi Syariah Teori dan Terapan Vol. 3 No. 5 Mei 2016: 359-374; PENGARUH BELANJA DAERAH TERHADAP INDEKS PEMBANGUNAN MANUSIA DI PROVINSI PAPUA PERIODE 2011 HINGGA 2013 DALAM PERSPEKTIF EKONOMI ISLAM

University, Hamedan Branch, Iran. Journal of Social and Behavioral Science, 131, hlm. 244-247, tersedia dalam www.sciencedirect.com

Sugiyono. 2009. Metode Penelitian Bisnis (Pendekatan Kuantitatif, Kualitatif dan R\&D). Jakarta: Alfabeta

Suparmoko, M. 2000. Keuangan Negara dalam Teori dan Praktek. Yogyakarta: BPFE-Yogyakarta

Wang, Fuhmei. 2015. More Health Expenditure, Better Economic Performance? Empirical Evidence from OECD Countries. The Journal of Health Care Organization, Provision and Financing, hlm. 1-5, tersedia dalam www.online.sagepub.com

Widodo, dkk. 2011. Analisis Pengeluaran Pemerintah di Sektor Pendidikan dan Kesehatan Terhadap Pengentasan Kemiskinan Melalui Peningkatan Pembangunan Manusia di Provinsi Jawa Tengah. Jurnal Dinamika Ekonomi Pembangunan Vol. 1 No. 1.

Wolf, Frieder dan Reimutt Zohlnhofer. 2009. Investing in human capial? The determinants of provate education expenditure in 26 OECD countries. Journal of European Social Policy, 19(3), hlm. 230-244

Yussof dan Nain. 2003. Konsep, Teori, Dimensi \& Isu Pembangunan. Johor: Universitas Teknologi Malaysia 